\title{
Transesterification of Tropical Edible Oils to Biodiesel Using Catalyst from Scylla serrata
}

\author{
Risfidian Mohadi ${ }^{1}$, Hesti A Harahap ${ }^{1}$, Nurlisa Hidayati $^{1}$, Aldes Lesbani ${ }^{1,2, *}$
}

${ }^{1}$ Department of Chemistry, Faculty of Mathematic and Natural Sciences, Sriwijaya University, Jl. Raya Palembang Prabumulih Km32 Ogan Ilir, South Sumatera, Indonesia

${ }^{2}$ Integrated Research Laboratory, Graduate School, Sriwijaya University Jl. Padang Selasa Bukit Besar Palembang 30139

*Corresponding author. email: aldeslesbani@yahoo.com

Article history

\begin{tabular}{llll} 
Received & Received in revised form & Accepted & Available online \\
26 May 2016 & 15 June 2016 & 29 June 2016 & 30 June 2016 \\
\hline
\end{tabular}

\begin{abstract}
Scylla serata shell was decomposed at various temperatures ranging from $700-1100{ }^{\circ} \mathrm{C}$ to obtain calcium oxide. Calcium oxide from decomposed Scylla serrata shell was characterized through X-Ray analysis, FTIR spectroscopy, and morphology analysis. Furthermore, decomposed Scylla serrata shell was used as catalyst for transesterification of tropical edible oils to form biodiesel. Biodiesel was characterized through density, viscosity, fatty acid value, and iodine number. The results showed that decomposed Scylla serrata shell at $900{ }^{\circ} \mathrm{C}$ could produce calcium oxide similar with standard, which was indicated from X-ray powder diffraction pattern of decomposed shell with JCPDS data. FTIR spectrum showed that main vibration of calcium oxide was observed at $393 \mathrm{~cm}^{-1}$. Morphology analysis using SEM indicated that uniform calcium oxide was obtained after decomposition. The use of decomposed shell as base catalyst for transesterification of tropical edible oils resulted biodiesel with density, viscosity, fatty acid value, and iodine number appropriated with SNI standard.
\end{abstract}

Keywords: transesterification, edible oils, biodiesel, Scylla serrata

\begin{abstract}
Abstrak (Indonesian): Scyalla serrata telah didekomposisi pada berbagai suhu dari $700-1100{ }^{\circ} \mathrm{C}$ untuk diperoleh kalsium oksida. Kalsium oksida hasil dekomposisi dari cangkang Scylla serrata dikarakterisasi melalui pengukuran sinar X, analisis FTIR, dan analisis morfologi. Lebih lanjut, dekomposisi cangkang Scylla serrata digunakan sebagai katalis transesterifikasi minyak yang dimakan dari daerah tropis menjadi biodisel. Biodiesel dikarakterisasi melalui penentuan densitas, viskositas, nilai asam lemak, dan bilangan iod. Hasil penelitian menunjukkan bahwa dekomposisi cangkang Scylla serrata pada $900{ }^{\circ} \mathrm{C}$ dapat menghasilkan kalsium oksida mirip kalsium oksida standar yang diindikasikan dari pola difraksi XRD yang mirip data JCPDS. Spektrum FTIR menunjukkan vibrasi utama kalsium oksida teramati pada bilangan gelombang $393 \mathrm{~cm}^{-1}$. Analisis morfologi menggunakan SEM menunjukkan bahwa bentuk yang lebih seragam diperoleh setelah proses dekomposisi. Penggunaan cangkang hasil dekomposisi sebagai katalis basa untuk transesterifikasi minyak yang dimakan dari daerah tropis menghasilkan biodisel dengan densitas, viskositas, nilai asam lemak, dan bilangan iod yang sesuai dengan standar SNI.
\end{abstract}

Kata kunci: transesterifikasi, minyak yang dimakan dari daerah tropis, biodiesel, Scylla serrata

\section{Introduction}

Biodiesel is renewable energy, which was produced from transesterification of vegetable oils or animal fats using acid or base catalysts. The advantages of biodiesel are biodegradable, environmentally benign, and low sulfur emissions [1-2]. Thus the development of biodiesel synthesis is growing up until this decade specially to obtain efficient catalyst for transesterification. Catalyst for transesterification has been divided into two groups i.e. homogeneous and heterogeneous catalysts [2]. Homogeneous catalysts have unreusability properties resulted high economic process. On the other hand, heterogeneous catalysts resulted solid materials after catalytic process thus potentially be reuse. Several heterogeneous catalysts for transesterification has been tested such as magnesium oxide [3], calcium oxide [4], zeolites [5], and also hydrocalcites [6]. Among these catalysts, calcium oxide is a potential base material due to high basic strength, low cost, and natural high availability also many reports has been published on calcium oxide catalyzed transesterification [7]. To make reaction more economic and sustainable, the use of natural calcium oxide from waste products such as shell of mollusk has been of recent interest [8]. Several shell mollusk has been evaluated as heterogeneous base catalysts for transesterification [9]. Our preliminary study also reveals the efficiency of Achatina fulica as catalyst for biodiesel 
production due to calcium oxide properties [10]. Other studies shows modification of egg shell can be conducted in order to search heterogeneous catalysts for biodiesel production [11]. Scallop shell also shows effective catalyst for biodiesel production [12]. Natural sources to obtain calcium oxide also can be performed using chicken and goat bones in order application as base catalyst for biodiesel production [13]. The objective of this paper is to evaluate ability of decomposed Scylla serrata shell as base catalyst for biodiesel production from tropical edible oils such as coconut oil, palm oil, and palm cooking oil. Finally, biodiesel was determined through density, viscosity, fatty acid value and iodine number.

\section{Experimental Sections}

\subsection{Materials}

Coconut and palm oils were obtained from traditional market in Palembang, South Sumatera and filtered prior to use. Scyalla seratta shell was obtained from several tradional market in Palembang. Scyalla serrata shell was washed, dried, and grounded with mortar to be pass 100 sieves. Chemicals were used directly after purchased from Merck such as ethanol, potassium hydroxide, hydrochloric acid, oxalic acid, potassium dichromate, chloroform, methanol, sodium thiosulfate, and potassium iodide.

\subsection{Preparation of base catalyst from Syclla serrata shell by decomposition \\ Catalyst from Scylla serrata shell was decomposed} at various temperatures $\left(700-1100{ }^{\circ} \mathrm{C}\right)$ using muffle furnace. Dried Scylla serrata shell (100 g) was calcined at certain temperature for $2 \mathrm{~h}$ under atmospheric oxygen, cooled a room temparature and stored in a dessicator. Characterization of Scylla serrata and decomposed shell at various temperatures was performed using X-Ray powder diffraction from Shimadzu Lab X Type 6000 at scanning $1 \mathrm{deg} / \mathrm{min}$ over $2 \theta$ range $0-90 \mathrm{deg}$, FTIR analysis using Shimadzu FTIR Prestige-21, and morphogy analysis using SEM JED-2300 Jeol.

\subsection{Transesterification of edible oil}

Transesterification of edible oils was conducted using $250 \mathrm{~mL}$ Schlenk Flask equipped with magnetic strirring. Decomposed shell (2\%wt) was added into Schlenk flask following with addition of $100 \mathrm{~mL}$ edible oils and $40 \mathrm{~mL}$ of methanol. The mixtures were stirred slowly for $3 \mathrm{~h}$ with closed system reflux. The reaction was stopped using cold water and mixtures were kept for overnight. In the mixture was added phosphoric acid (2 $\mathrm{mL}$ ) following with extraction to obtain crude biodiesel. Crude biodiesel was distilled to obtain pure biodiesel.

\subsection{Characterization of biodiesel}

Biodiesel from transesterification of edible oils was characterized through determination of density (ASTM D-1298), viscosity (ASTM D-4445), acid value (ASTM D-664), and iodine number (AOCS Cd1-25).

\section{Result and Discussion}

Scylla serrata is one species of crab and their shell contains calcium carbonate. Decomposition of calcium carbonate can produce calcium oxide. Due to concentration of calcium carbonate in Scylla serrata shell depending on their habitat and environment condition, the decomposition should be conducted in various temperatures to obtain calcium oxide. Calcium oxide from decomposition for each temperature was characterized using X-Ray powder analysis. The pattern was compared with the data from Joint Committee on Powder Diffraction Standard (JCPDS) for calcium oxide and related compounds as shown in Table 1. Diffraction pattern of shell after decomposition for each temperature is presented in Figure 1.

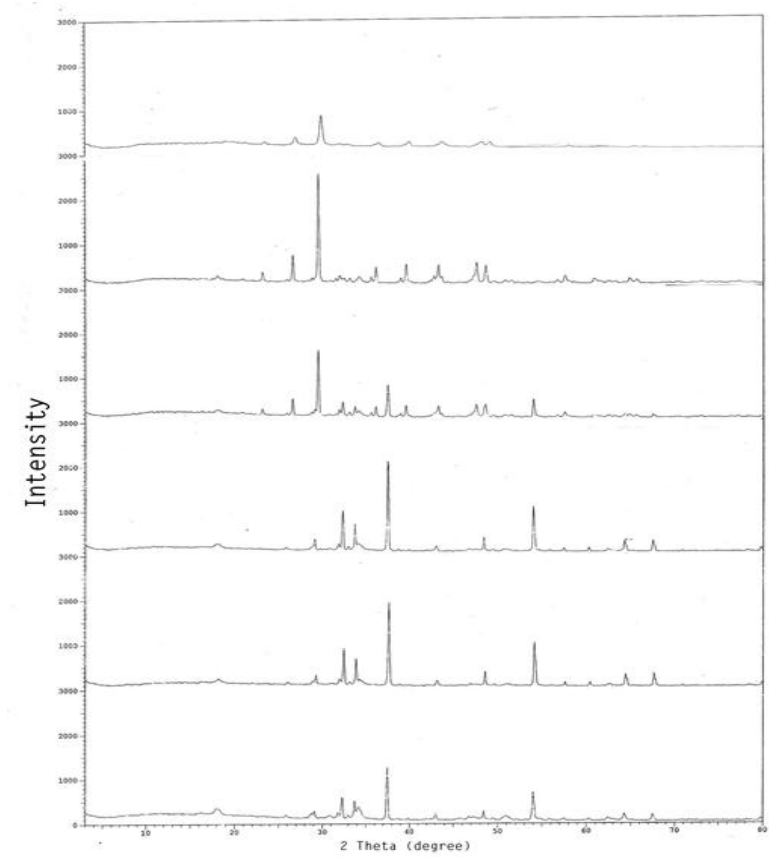

Figure 1. XRD powder patterns of decomposed Scylla serrata at various temperatures decomposition.

The X-Ray pattern in Figure 1 showed that decomposition shell at temperature 700 and $800{ }^{\circ} \mathrm{C}$ still contain calcium carbonate as raw material, which was indicated from diffraction at 28-29 deg. By increasing temperature decomposition to $900{ }^{\circ} \mathrm{C}$ slightly changed the X-Ray pattern. Diffraction at 28-29 deg was fully reduced and diffraction at 37-40 deg was appeared clearly. Diffraction at 37-40 deg was assigned as calcium oxide. Thus by decomposition at $900{ }^{\circ} \mathrm{C}$ can decompose Scylla serrata shell to calcium oxide with small concentration calcium carbonate remained. Further experiment was tried by increasing decomposition 
temperature to $1000-1100{ }^{\circ} \mathrm{C}$. The X-Ray pattern of shell after decomposition $1000-1100{ }^{\circ} \mathrm{C}$ as shown in Figure $1 \mathrm{E}-\mathrm{F}$ was similar with decomposition at $900{ }^{\circ} \mathrm{C}$. These results showed that relative mild condition for decomposition of Scylla serrata was obtained at $900{ }^{\circ} \mathrm{C}$. Further Characterization of decomposed shell at $900{ }^{\circ} \mathrm{C}$ was carried out using FTIR spectroscopy and the FTIR spectrum was shown in Figure 2.

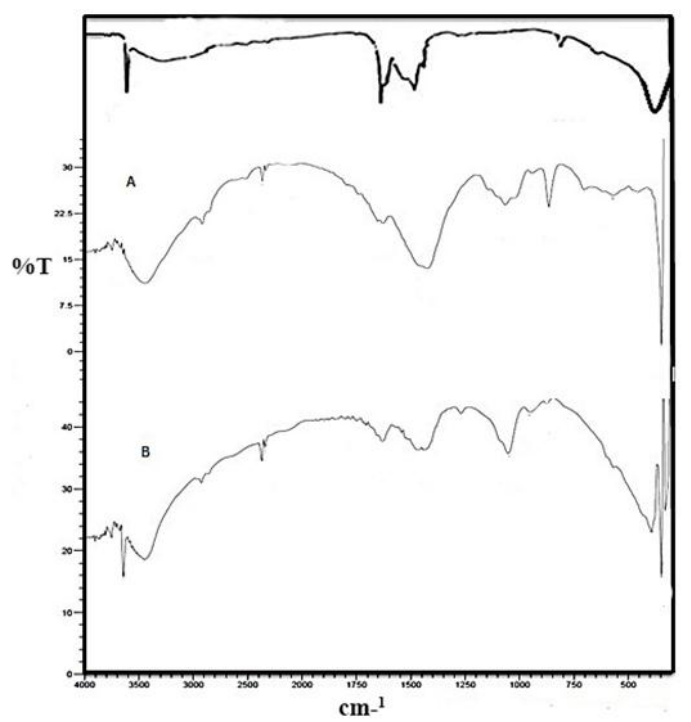

Figure 2. FTIR spectrum of calcium oxide standard (upper); Scylla serrata shell (A); and decomposed Scylla serrata at $900{ }^{\circ} \mathrm{C}(\mathrm{B})$.

Comparison of FTIR spectrum of decomposed shell with FTIR standard of calcium oxide indicated that decomposition at $900{ }^{\circ} \mathrm{C}$ was enough for Scylla serrata shell to produce calcium oxide similar with standard. In this experiment, FTIR spectrum of Scylla serrata shell was also identified as shown in Figure 2A. There is small changes vibration of calcium in this research especially in the range of $300-900 \mathrm{~cm}^{-1}$. The main vibration of calcium oxide was observed at wavenumber $390 \mathrm{~cm}^{-1}$ [14]. This vibration was clearly observed in Figure 2B. In order to know detail of decomposition process, characterization was attempted using SEM analysis. Morphology of Scylla serrata shell before and after decomposition was shown in Figure 3.

Analysis of SEM photo in Figure $3 \mathrm{~A}$ and $3 \mathrm{~B}$ indicated that the shape of shell to be uniform was occurred. The size of shell also reduced after decomposition process. These results indicated that the decomposition process was successfully obtained in this research.

The second step of this experiment was application of decomposed shell at $900{ }^{\circ} \mathrm{C}$ as base catalyst for transesterification of tropical edible oils such as coconut oil, palm oil, and also waste palm cooking oil. Transesterification was conducted using methanol and the reaction mixtures was carefully handle overnight after $3 \mathrm{~h}$ reflux process. Distillation was carried out in order to obtain pure biodiesel after quench overnight. Biodiesel was characterized through density, viscosity, fatty acid value, and iodine number. The results for each characterization were presented in Table 2-5.

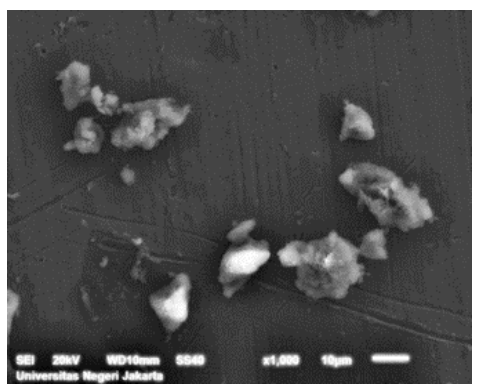

(A)

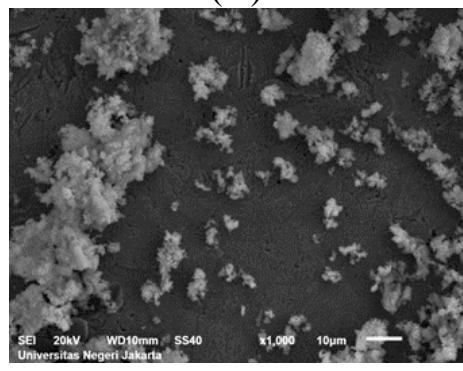

(B)

Figure 3. Morphology of Scylla serrata (A) and Scylla serrata after decomposition at $900{ }^{\circ} \mathrm{C}$ (B).

Table 1. Diffraction standard of calcium compounds

\begin{tabular}{lllllc}
$\begin{array}{l}\text { Calcium } \\
\text { compounds }\end{array}$ & $2 \theta(\mathrm{deg})$ & & & \\
\hline $\mathrm{CaO}$ & 32.2 & 37.3 & 58.3 & 64.1 & 67.3 \\
$\mathrm{CaCO}_{3}$ & 29.4 & 39.4 & 43.2 & 47.4 & 48.5 \\
$\mathrm{Ca}(\mathrm{OH})_{2}$ & 28.6 & 34.1 & 47.1 & 50.8 & - \\
\hline
\end{tabular}

Table 2. Fatty acid value of edible oils before and after transesterification

\begin{tabular}{lll}
\hline Edible Oils & $\begin{array}{l}\text { Before } \\
\text { Transesterification } \\
(\mathrm{mg} / \mathrm{KOH})\end{array}$ & $\begin{array}{l}\text { After } \\
\text { Transesterification } \\
(\mathrm{mg} / \mathrm{KOH})\end{array}$ \\
\hline Coconut oil & 1.85 & 0.12 \\
Palm oil & 3.95 & 0.18 \\
Palm & 4.83 & 0.19 \\
cooking oil & &
\end{tabular}

Standard fatty acid value for biodiesel was maximum 0.8 $\mathrm{mg} / \mathrm{KOH}$

Table 3. Viscosity of edible oils

\begin{tabular}{lll}
\hline Edible Oils & $\begin{array}{l}\text { Before } \\
\text { Transesterification } \\
(\mathrm{cSt})\end{array}$ & $\begin{array}{l}\text { After } \\
\text { Transesterification } \\
(\mathrm{cSt})\end{array}$ \\
\hline Coconut oil & 21.62 & 2.43 \\
Palm oil & 34.06 & 3.63 \\
Palm & 48.25 & 5.26 \\
cooking oil & & \\
\hline
\end{tabular}

Standard viscosity for biodiesel was in the range 0.2-6.0 cSt. 
Table 4. Density of edible oils

\begin{tabular}{|c|c|c|}
\hline Edible Oils & $\begin{array}{l}\text { Before } \\
\text { Transesterification } \\
\left(\mathrm{g} . \mathrm{cm}^{-3}\right)\end{array}$ & $\begin{array}{l}\text { After } \\
\text { Transesterification } \\
\left(\mathrm{g} . \mathrm{cm}^{-3}\right)\end{array}$ \\
\hline Coconut oil & 0.88 & 0.86 \\
\hline Palm oil & 0.87 & 0.87 \\
\hline $\begin{array}{l}\text { Palm cooking } \\
\text { oil }\end{array}$ & 0.89 & 0.86 \\
\hline
\end{tabular}

Table 5. Iodine number of edible oil

\begin{tabular}{lll}
\hline Edible Oils & $\begin{array}{l}\text { Before } \\
\text { Transesterification } \\
\left(\mathrm{g} \mathrm{I}_{2} / 100 \mathrm{~g}\right)\end{array}$ & $\begin{array}{l}\text { After } \\
\text { Transesterification } \\
\left(\mathrm{g} \mathrm{I}_{2} / 100 \mathrm{~g}\right)\end{array}$ \\
\hline Coconut oil & 114.23 & 29.23 \\
Palm oil & 134.0 & 104.76 \\
Palm & 149.98 & 105.98
\end{tabular}

cooking oil

Standard iodine number for biodiesel was maximum 115 $\mathrm{g} \mathrm{I}_{2} / 100 \mathrm{~g}$.

Biodiesel from characterization in Table 2-5 was compared with standard data from SNI (National Indonesia Standard) for biodiesel. All characterization toward biodiesel from edible oils shows appropriate value in the range of standard. Thus this research can be used as a candidate for renewable energy in the future.

\section{Conclusion}

Transesterification of tropical edible oils using decomposed Scylla serrata shell at $900{ }^{\circ} \mathrm{C}$ as base catalyst form biodiesel up to $68 \%$. Biodiesel from various edibles oil in Indonesia has viscosity, density, fatty acid, and iodine number in the range of biodiesel from SNI.

\section{Acknowledgement}

This research was supported from Dikti, Republic of Indonesia through Hibah Fundamental 2012-2013 and Sriwijaya University 2014-2015. Authors are grateful to Department of Chemistry, Faculty of Mathematic and Natural Sciences, Sriwijaya University.

\section{References}

[1] S. Ramkumar and V. Kirubakaran, "Biodiesel from vegetable oil as alternate fuel for C.I engine and feasibility study of thermal cracking: A critical review," Energy Convers. Manag., vol. 118, pp. 155-169, 2016.

[2] B. K. Uprety, W. Chaiwong, C. Ewelike, and S. K. Rakshit, "Biodiesel production using heterogeneous catalysts including wood ash and the importance of enhancing byproduct glycerol purity," Energy Convers. Manag., vol. 115, pp. 191-199, 2016.

[3] H. Jeon, D. J. Kim, S. J. Kim, and J. H. Kim, "Synthesis of mesoporous $\mathrm{MgO}$ catalyst templated by a PDMS-PEO comb-like copolymer for biodiesel production," Fuel Process. Technol., vol. 116, pp. 325-331, 2013.
[4] Y. Tang, J. Xu, J. Zhang, and Y. Lu, "Biodiesel production from vegetable oil by using modified $\mathrm{CaO}$ as solid basic catalysts," J. Clean. Prod., vol. 42, pp. 198-203, 2013.

[5] A. M. Doyle, T. M. Albayati, A. S. Abbas, and Z. T. Alismaeel, "Biodiesel production by esterification of oleic acid over zeolite Y prepared from kaolin," Renew. Energy, vol. 97, pp. 19-23, 2016.

[6] Y.-T. Wang, Z. Fang, F. Zhang, and B.-J. Xue, "One-step production of biodiesel from oils with high acid value by activated $\mathrm{Mg}-\mathrm{Al}$ hydrotalcite nanoparticles," Bioresour. Technol., vol. 193, pp. 84-89, 2015.

[7] R. Shan, G. Chen, B. Yan, J. Shi, and C. Liu, "Porous $\mathrm{CaO}$-based catalyst derived from PSSinduced mineralization for biodiesel production enhancement," Energy Convers. Manag., vol. 106, pp. 405-413, 2015.

[8] J. Boro, L. J. Konwar, A. J. Thakur, and D. Deka, " $\mathrm{Ba}$ doped $\mathrm{CaO}$ derived from waste shells of $\mathrm{T}$ striatula (TS-CaO) as heterogeneous catalyst for biodiesel production," Fuel, vol. 129, pp. 182-187, 2014.

[9] N. Viriya-empikul, P. Krasae, B. Puttasawat, B. Yoosuk, N. Chollacoop, and K. Faungnawakij, "Waste shells of mollusk and egg as biodiesel production catalysts," 2010.

[10] A. Lesbani, P. Tamba, R. Mohadi, and F. Fahmariyanti, "PREPARATION OF CALCIUM OXIDE FROM Achatina fulica AS CATALYST FOR PRODUCTION OF BIODIESEL FROM WASTE COOKING OIL," Indones. J. Chem., vol. 13, no. 2, pp. 176-180, 2013.

[11] S. Niju, K. M. Meera, S. Begum, and N. Anantharaman, "Modification of egg shell and its application in biodiesel production," J. Saudi Chem. Soc., vol. 18, no. 5, pp. 702-706, 2014.

[12] S. Sirisomboonchai, M. Abuduwayiti, G. Guan, C. Samart, S. Abliz, X. Hao, K. Kusakabe, and A. Abudula, "Biodiesel production from waste cooking oil using calcined scallop shell as catalyst," Energy Convers. Manag., vol. 95, pp. 242-247, May 2015.

[13] A. Lesbani, Y. Susi, M. Verawaty, R. Mohadi, and R. Mohadi, "Calcium Oxide Decomposed From Chicken's and Goat's Bones as Catalyst For Converting Discarded Cooking Oil to be Biodiesel," Aceh Int. J. Sci. Technol., vol. 4, no. 1, Jan. 2015.

[14] W. Roschat, T. Siritanon, B. Yoosuk, and V. Promarak, "Biodiesel production from palm oil using hydrated lime-derived $\mathrm{CaO}$ as a low-cost basic heterogeneous catalyst," Energy Convers. Manag., vol. 108, pp. 459-467, 2016. 